\title{
Giving Birth, Transhumanism and Human Nature
}

\author{
Sobre o parto, transhumanismo e natureza humana
}

EDUARDO R CRUZ iDa

\begin{abstract}
Philosopher Fiona Wollard recently advocated interpreting the achievements of women while giving birth. People readily recognize men-related achievements, like running a marathon, but not achievements related to giving birth. We expand on Woollard's notion of reproductive achievements, comparing them with ideas of human enhancement, which aims at humans becoming "stronger and faster". Criticisms to evolutionary psychology challenge its defense of a notion of a fixed human nature, and its disregard for the experience of birth. Some female scholars link human evolution to the presence of premature infants requiring attention from mothers and alloparents. They explain why this gave an advantage to the human species, enhancing cooperation and other desirable traits. Other scholars develop philosophies of birth, mostly based on Arendt's conception of natality, questioning a human nature not sensitive to gender, excluding birth and childhood. Then we move to transhumanism, proponent of human enhancement. Transhumanism questions our biological inheritance for being flawed and outdated, including giving birth, restricting this to a source of great suffering. This assessment of the given does not consider its ambiguous, dialectical character. Because of that, tinkering with nature both accomplishes and frustrates the goals of human enhancement.
\end{abstract}

Keywords: Human nature. Evolution. Birth. Transhumanism. Natality.

\section{Resumo}

A filósofa Fiona Wollard defendeu recentemente interpretar das conquistas as mulheres durante o parto. As pessoas reconhecem prontamente as realizações relacionadas aos homens, como correr uma maratona, mas não as realizações relacionadas ao parto.

\footnotetext{
a Pontifícia Universidade Católica de São Paulo (PUC-SP), São Paulo, SP, Brasil . Doutor em teologia sistemática, e-mail: erodcruz@gmail.com
} 
Desenvolvemos a noção de realizações reprodutivas de Woollard, comparando-as com ideias de aprimoramento humano, que visa tornar os humanos "mais fortes e mais rápidos". As críticas à psicologia evolucionista desafiam sua defesa de uma noção de uma natureza humana fixa e seu desprezo pela experiência do nascimento. Algumas estudiosas vinculam a evolução humana à presença de bebês prematuros que requerem atenção das mães e aloparentes. Elas explicam por que isso deu uma vantagem à espécie humana, aumentando a cooperação e outras características desejáveis. Outros estudiosas desenvolvem filosofias de nascimento, principalmente com base na concepção de natalidade de Arendt, questionando uma natureza humana não sensível ao gênero, excluindo nascimento e infância. Em seguida, passamos para 0 transhumanismo, proponente do aprimoramento humano. O transhumanismo questiona nossa herança biológica por ser imperfeita e desatualizada, incluindo o parto, restringindo este a uma fonte de grande sofrimento. Essa avaliação do dado não considera seu caráter ambíguo e dialético. Por causa disso, mexer com a natureza tanto realiza quanto frustra os objetivos do aprimoramento humano.

Palavras-chave: Natureza humana. Evolução. Nascimento. Transhumanismo. Natalidade.

\section{Introduction}

Not long ago, philosopher Fiona Wollard published a contribution to the magazine Aeon, with the title, "Philosophy can explain what kind of achievement it is to give birth" (WOOLLARD, 2020). This contribution was prompted by an email she received, complimenting a male colleague of the department for his achievement, completing a marathon. She commented on the feat with female friends of hers, to the effect that people were more likely to recognize man-related achievements, than to recognize another achievement comparable to running a marathon, namely, a woman giving birth to a child.

Her proposal of a philosophy of birth served as a cue for some reflections of ours on human nature, from the perspective of giving birth and childhood. We first expand on Woollard's argument, with her notion of "gender embodied reproductive achievements." The term "achievements," on the other hand, evokes the idea of human enhancement, with its goal of "stronger and faster." But before engaging this idea, we discuss criticisms to evolutionary psychology for giving too much emphasis on a fixed human nature, and its disregard for the experience of birth. To cover this lacuna, we resort to a few female scholars who link human evolution to the presence of premature infants that require attention from the mother and alloparents. They 
explain why this gave an advantage to the human species, enhancing cooperation and other desirable traits.

Then we refer to other scholars who develop philosophies of birth, mostly based on Arendt's conception of natality. These approaches also question a notion of human nature which is not sensitive to gender, excluding giving birth and childhood. After this more introductory section, we move to transhumanism, a global movement that denies current human condition and advocates either the enhancement of this condition or its overcoming altogetherb. We analyze how this movement questions our biological inheritance for being flawed and outdated. More specifically, when transhumanists turn their attention to all that is involved in giving birth, they restrict it to a source of great suffering.

We respond to this assessment of the given (human nature, human condition, human identity) by showing that the given refers to an ambiguous, dialectical situation-the very flaws that transhumanists seek to correct are also sources of possible happiness. Tinkering with nature, therefore, both accomplishes and frustrates the goals of human enhancement.

\section{Running a marathon versus giving birth}

Woollard calls our attention to a crucial aspect that defines humans, one that it is related to our gendered nature. Insofar as it is associated with excellent performance, it is of direct interest in debates about enhancement. According to Woollard,

During pregnancy, birth and the early days of parenthood, humans do amazing things with our bodies, easily comparable to the achievements of any marathon runner...

We push the boundaries of human endurance with peaks of energy use comparable to those of elite athletes (WOOLLARD, 2020).

Indeed, some of the effort by transhumanists and like-minded people concerns the enhancement of elite athletes to out-perform what is species-typical, through drugs, genetic manipulation, prostheses, etc. (MIAH, 2010). These proposals have

\footnotetext{
$\mathrm{b}$ The literature around transhumanism is legion. For more information on the movement, see contributions to the special issue of the journal Aurora, vol. 32/55, jan/april 2020.
} 
raised a heated discussion (e.g., MCNAMEE, 2013), including criticism of ableism (especially when considering disabled people) (WOLBRING, 2009, 2010), criticism of male-oriented selection of abilities (KEELING, 2012), and (implicit or explicit) references to human nature and dignity. But the discussion is restricted mainly to sports and does not consider Woollard's example of childbirth, so we will leave sports aside in this text.

Woollard suggests not only that any thoughts about human nature, essentialist or not, should be gender-related, but also that pregnancy, giving birth and nurturing the child are at the basis of what we would count as human nature (she does not use this expression), something that we usually ignore. These female-related traits "are treated very differently from other physical achievements, such as running marathons" (WOOLLARD, 2020). These gender-specific feats are what the author calls "gendered embodied reproductive achievements, or GERAs" (ibid.). It is certainly a problem to restrict women to GERAs, labeling those who remain childfree as less of a woman, as many feminists have rightly pointed out. Woollard herself speaks of the "idolization" of "vaginal birth and breastfeeding," that is, seeing them as "essential badges of good motherhood." But criticizing stereotypes does not rule out seeing these activities as pivotal in the life-experiences of the average woman.

On the other hand, we may have the problem of insensitivity, minimizing the importance of these experiences. For Woollard, "The result is that pregnant, birthing and lactating people are divided from their bodies and told not to talk about or feel good about significant experiences" (Ibid.). Common to these extremes are traits such as essentialism (measuring all of women's experiences by the same yardsticks), and misattribution ("achiever" mothers are not necessarily the best mothers). As it is true with many other scholars nowadays, Woollard is wary of speaking about some "mother nature," as if it were a branch of human nature. That is why she equates "GERAs such as pregnancy, birth and breastfeeding" with "running a marathon," (ibid.) stressing both the achievement and the matter of choice-not all women will choose to be a "winning mother", and there is nothing wrong about that.

Yet, as we judge it, there is a wide gap between these two situations: running marathons is a latecomer in human history, whereas optimal reproduction is essential to the success of the human species. Indeed, besides the cultural history of birth, open 
to individual choices and to relativism, we should pay attention to the natural history of birth as a pivotal element of the evolutionary history of humankind. This insight draws our attention to the discussion about human nature.

\title{
Human nature, a contested concept
}

The notion of Human Nature has been hotly debated in the last few decades (DOWNES; MACHERY, 2013) involving, roughly speaking, four main actors: (1) "bioconservatives,"c traditional defenders of human nature and dignity (people such as Francis Fukuyama, Jürgen Habermas, and disciples of Hans Jonas-Leon Kass among others), (2) evolutionary scholars themselves, mainly sociobiologists and evolutionary psychologists, (3) cultural studies scholars (including representatives of feminist theory), wary of natural histories and supporters of social constructionism, and (4) those who promote human enhancement. However, we will not engage this debate as such, giving instead some attention to the question of giving birth, coming across some claims of these four groups.

Scholars of human evolution and behavior do use the term "human nature" $(\mathrm{HN})$ a lot, even though there have been some criticisms of its use in the last few decades. For example, John Cartwright's well-known manual Evolution and Human Behavior changed the subtitle, from "human nature" in the second edition (2008) to "human condition" in the third edition (2016). As he himself explains:

\begin{abstract}
This time-honoured phrase, 'human condition', is better, I think, than the dangerously essentialist concept of 'human nature' (used in the subtitle of the second edition), in that it more adequately conveys the central idea of this book of an evolved genetic programme shaped by the unwavering forces of natural and sexual selection, unfolding in, and moulded by, constantly varying environmental circumstances and influences. Furthermore, the term 'condition' captures the fact that our evolutionary heritage underpins many modem predicaments that humans struggle to deal with and understand (CARTWRIGHT, 2016, xxiii).
\end{abstract}

Insofar as the focus is on "modern predicaments," his change of mind seems warranted. But what if we focus instead on the Environment of Evolutionary Adaptedness (EEA), as it is called in evolutionary psychology, referring to that ancestral environment in which the present shape of human mind took place? As philosopher of biology Stephen M. Downes presents in his contribution to the

\footnotetext{
c For the notion of bioconservatism, see Lopes (2020, p. 42 ss.). 
Stanford Encyclopedia of Philosophy, there are at present two understandings in Evolutionary Psychology (EP) of the concept of human nature, one "hard" and the other "soft". He starts with EP pioneers Tooby and Cosmides, to the effect that "the concept of human nature is based on a species-typical collection of complex psychological adaptations" (DOWNES, 2018). He then mentions scholars still willing to keep some normative form of human nature, such as philosopher Edouard Machery, who stresses universals from our evolutionary past.

Critics (such as Hull, Buller, Lewens, Ramsey), on the other hand, emphasize the role of variation in evolution: "humans, like all organisms, exhibit a great deal of variation, including morphological, physiological, behavioral and cultural variation," (Ibid.,) rendering as almost useless the notion of a fixed human nature. Yet, the use of $\mathrm{HN}$ is widespread, not only in common parlance, but in scholarly publications as well. Cartwright's own reservations notwithstanding, he himself has several mentions to $\mathrm{HN}$ in his book. Whatever the standing of these discussions, there are signs that it still is male oriented talk. ${ }^{\mathrm{d}}$

For example, a whole issue of the journal Philosophy and Technology (25, 2012), dedicated to human nature and enhancement, has only one article with references to women, without much emphasis on their experience of giving birth (EARP; SANDBERG; SAVULESCU, 2012). It is true that one of the reasons given for the refusal of human nature is the misogynous, racist and colonialist overtones of the term. But scholars still have difficulties in discussing the female side in the study of human evolution. Going back to Cartwright's manual, the book has only two pages dedicated to giving birth, so we see the importance of going back to this very human experience.

\section{Human nature, female style}

Philosopher Orli Dahan, for example, criticizes mainstream EP for not taking into account the adaptive role of childbirth, considering its crucial importance for successful reproduction. Dahan argues that "understanding the mental and behavioral

\footnotetext{
d For a more detailed account of this controversy, see Kronfeldner, Roughley and Toepfer (2014), and Lopes (2020, p. 54 ss.).
} 
state of women during natural birth can teach us more about the human mind and behavior" (DAHAN, 2021, p. 6; italics hers). Among the many possibilities of research, her focus is on what is called "birthing consciousness," defined as

a unique psycho-physical state of focus and retreat that happens during natural-undisturbed labor in which the archaic brain releases the hormones of labor, enabling easier birth, reduced pain, and better health outcomes for the birthing woman and her newborn (Ibid.).

Her focus highlights the active role of the parturient, the woman being an active agent during the crucial event of birthing. On the other hand, this focus underscores the cooperative character of childbirth in human beings. As she states, "In humans, direct care around the time of birth is the most significant kind of investment kin make to guarantee the survival and reproduction of birthing women and their babies." (Ibid., p. 3) Finally, as many others have pointed out in recent decades, modern medical practice disturbs natural childbirth in many ways. Her work builds upon mainly female researchers in anthropology and medicine, such as Sarah Hrdy and Wenda Trevathan, who wrote extensively on mothering, childbirth and related issues.

Contrariwise to current proposals of enhancement, which point to technologically driven ways to correct what was given to us in the EEA, these authors defend going back to natural ways in childbirth, without giving up modern medicine. Let us summarize some of their arguments.

Trevathan and Karen Rosenberg, for example, go way back to a reference in 1962 by Theodosius Dobzhansky, to ground their assertion that "that it was humans' helplessness at birth and utter dependence on parents and other caretakers that favored learning and socialization 'on which the transmission of culture wholly depends"' (TREVATHAN; ROSENBERG, 2016, p. 1). Even if we do not enter into the realm of culture, they argue, "Many of the distinctive characteristics that make us human can trace their origins (or at least their significance) to the fact that we give birth to infants who are highly dependent on others" (ibid.). So, considering the status of adults, men or women, to account for the causes of adaptation, equal in importance is the helpless, cute infant (ibid., p. 2). There are not only costs, but also benefits (trade-offs), of giving birth to an immature offspring, and social and cultural adaptation is one of the benefits of assistance in human birth. In other words, 
"cooperative breeding" is "central to the distinctive aspects of human life history" (Ibid., p. 3).

In sum, "birth . . . is a point when the neonate leaves the relative isolation of the biological womb of the uterus and enters the larger, more stimulating cultural womb of the mother and her social group" (Ibid., p. 4). Moreover, infants themselves are not passive recipients of general attention, since they are "able to manipulate aspects of their environment through their attractiveness (cuteness)" (Ibid.). All in all, it is the very wealth of problems and dangers surrounding childbirth, in particular those referring to a narrow birth canal, that helps to account for the sublimity of humankind, comprising beings that care about others, even non-kin.

It is not difficult to see other scholars making similar claims. For example, Darcia Narvaez and colleagues argue that in modern society "the needs of 'the mammalian' brain-mind have been supplanted by 'advanced' cultural practices that may be losing touch with our ancestral needs" (NARVAEZ et.al., 2013, p. 6). Based on Trevathan, they too state that "Current birthing and childrearing practices no longer come close to the traditional practices of evolved, expected care" (Ibid., p. 7). The importance of natural rhythms is also seen in the process of strengthening the immune system: "Human mothers, who provided immunity through the placenta [and vaginal birth], continue to provide immunity after birth, first with colostrum immediately after birth and thereafter with breast milk" (Ibid., p. 8). Tinkering with traditional cooperative breeding also has its drawbacks: "In contrast to our ancestral context, modern life includes several caregiving arrangements that most likely compromise optimal child development" (Ibid., p. 14; see also BUCKLEY, 2003, p. 264-265; SCHÜES, 2017, p. 110-111).

The message is neither that "nature is best," nor that "modern medicine is bad," but rather that tinkering with nature both accomplishes a better standard of living and fails to do so. It is true that, from a scientific point of view, there is no "human nature" in the past, a golden age paradigm to model current behavior. Yet, the optimality achieved in the EEA regarding successful reproduction still informs what a human being is all about. As many have indicated, "advanced" cultural practices (such as in proposals of enhancement) do not mean "better" conditions for 
the human (e.g., TEMKIN, 2011), especially if they do not take the central role of reproduction into account.

So we have two conclusions at this point: first, any talk about "human nature" should be gendered and a central role given to birth; second, to highlight birth means looking at the evolutionary past in a more benevolent fashion, which is precisely what, as we will see, transhumanists do not do. Let us leave the evolutionary framework for a moment and turn our attention to Woollard's concern: a philosophy of birth.

\title{
What kind of nature is comprised in a philosophy of birth?
}

Woollard is not a pioneer in developing a philosophy of birth. Many have done so in more or less explicit terms. To name just a few scholars, we may indicate Imogen Tyler (2009), Christina Schües (2017), Alison Stone (2019) and Fanny Söderbäck (2019).

These philosophers of birth, on their turn, usually refer to a seminal concept by philosopher Hannah Arendt, the concept of natality. As Arendt states,

\begin{abstract}
Since we all come into the world by virtue of birth, as newcomers and beginnings, we are able to start something new; without the fact of birth we would not even know what novelty is, all 'action' would be either mere behavior or preservation. No other faculty except language, neither reason nor consciousness, distinguishes us so radically from all animal species (ARENDT, 1970, p. 82).
\end{abstract}

Ironically, she attributes biological, embodied birth to the private sphere, having in higher regard the "second birth", the ability to begin anew through action, mainly political action (SÖDERBÄCK, 2019, p. 60). Arendt's many commentators have corrected this dichotomy. As Lisa Guenther criticizes,

the opposition between a laborious, private, and feminine labor of reproduction and an active, public, political, and apparently sexually undifferentiated 'second birth' conspires to reduce the maternal body to a biological or animal condition for a human existence from which she herself is excluded (GUENTHER, 2006, p. 40).

Nevertheless, "human existence is natal, that is, is as it is because we are born" (STONE, 2019, p. 1). Again, human identity stems from the sheer fact that we are born in a specific fashion. The stress on novelty may be related to what Christina Schües calls "disruption and transformation" caused by birth. According to her, birth "disrupts the life of the woman who gives birth to the child and of the persons for 
whom a child is born" (SCHÜES, 2017, p. 105). For example, the woman becomes a mother and a family is (re-) manifested. Especially for the child,

birth... means a transition from the intrauterine position to the extrauterine situation in the world, a transformation from living in the womb, with a surrounding wall and in a maternal-fetal relation, to a life in the world and in concrete different relationships and contexts... [a] fundamental leap [occurs] from one existential mode of being to another (Ibid., p. 106).

Taking the cue from Schües, that "Birth is the beginning of difference" (Ibid., p. 108), we may conclude again that birth of new humans does make a big difference for the understanding of who we are. Having in mind Sarah Hrdy's notion of "cooperative breeding," the birth of a new child represents an opportunity of enhanced cooperation, a benevolent disruption of customary ways of being. We may see a congruence between studies of birth in scientific oriented anthropological studies of the present and of the evolutionary past on the one hand, and on the other philosophical studies which highlight the agency of women while giving birth, as well as the central role this agency plays in configuring human identity.

Emphasizing an important point once again, these generalizations on women, on giving birth and on new generations do not warrant a fixed view of human nature-there is too much variation, both due to individual decisions (for example, some women decide not to have children; and transgender and non-binary people can also conceive children) and to cultural differences. Yet, generalizations are needed for human thought. Quoting Schües again, the relationship established by people of interest around a new birth is a "contingent yet irreplaceable relation" (Ibid., p. 107).

\section{Transhumanism, the evolution of the human, and birthing}

Now that we have glimpses of the cruciality of new births for the definition of human identity, we may go back to proposals of enhancement. First, pro-enhancers have criticisms of what results from EEA, arguing that evolution has done a poor job when it comes to humans. Second, they criticize any mention of "human nature," as this is the hallmark of "bioconservatism."

Let us expand on the first point. In his "Letter to Mother Nature," leading transhumanist Max More says, "With all due respect, we must say that you [Mother 
Nature] have in many ways done a poor job with the human constitution. ... We have decided that it is time to amend [it]" (MORE, 2013 [1999], p. 449). He then lists seven recommended amendments, including mastery over our biological and neurological processes (i.e., to fix all defects in individuals and the species as a whole, which are left over from the process of evolution by natural selection) and the reshaping of our motivational patterns and emotional responses (MORE, 2013 [1999], p. 450). This sentiment is echoed by Julian Savulescu and Anders Sandberg, also leading transhumanists, who have stated, "We need all the help we can get to liberate ourselves from evolution” (SAVULESCU; SANDBERG, 2012, p. 29)

Nick Bostrom and Anders Sandberg (2008) offer us a somewhat detailed study of the evolution of the brain. They acknowledge the "wisdom of nature" (evolutionary optimality) behind evolution, but only to the extent that it points to its own overcoming. Bostrom and Sandberg end up with a somewhat dismal view of the processes of nature. According to these authors, "Even if evolution had managed to build the finest reproduction-and-survival machine imaginable, we may still have reason to change it because what we value is not primarily to be maximally effective inclusive-fitness optimizers" (2008, p. 379). They not only see a mismatch between evolutionary processes and "what we value", but also see the mismatch between ancestral optimal conditions and the modern environment as something negative, detrimental to survival in contemporary society. Russell Powell and Allen Buchanan agree to some extent with this, but they are even more critical of evolution: "The ubiquity of suboptimal design demonstrates that natural selection is a bricoleur, not an engineer, much less a master engineer" (POWELL; BUCHANAN, 2011, p. 10).

Transhumanists remind us, quite rightly, that "Mother Nature" was not very kind to mothers, due to the difficult compromise between babies' big brains and their means of coming into the world. According to Powell and Buchanan, "the birth canal, which passes through the female pelvis thanks to selection's hasty rearrangement of hominid posture, dramatically increas[es] the risks of childbirth. The list [of unfavorable traits] goes on and on" (2011, p. 10). We see that there is no mention of trade-offs here. Artificial intelligence (AI) expert Bruce F. Katz (2008, p. 45) also points out the downside of large brains: the birthing process is painful and dangerous; 
babies are born prematurely; there is an increased dependency on parents; and babies have big and fragile skulls (KATZ, 2008, p. 356-57).

Transhumanists do not spare words in describing the haphazard nature of evolution as a source of unimaginable suffering (POWELL; BUCHANAN, 2011, p. 18). The reaction against this state of affairs is equally strong: "I find it impossible to blindly accept the suffering imposed upon us by our biological condition" (YOUNG, 2006, position 91). As evolution has done a poor job, various technological solutions to this problem have been forwarded, in addition to the use of extrauterine environments. One solution, which can leave the birthing process mostly untouched, is to have "designer babies," minimizing problems at birth, extending existing technologies of in vitro fertilization to help pave the way to posthumanity (YOUNG 2006). Extrauterine pregnancy and birth is certainly the most radical proposal:

[...] ectogenesis, which is the development of embryos in artificial conditions outside of a woman's uterus-normally using artificial uteruses to create human children. This is celebrated news, besides aspects of childbirth to be grueling, physically distressing, and painful; furthermore, it may one day become completely unnecessary (PEED, 2016, p. 506).

There are more nuanced proposals, such as the "procreativity beneficence" of Savulescu and Kahane (2009): "If couples (or single reproducers) have decided to have a child, and selection is possible, then they have a significant moral reason to select the child, of the possible children they could have" (p. 274). Even more radically, for some, even "designer babies" will not be necessary, since there will be more efficient ways to produce posthumans".

The 'designer baby' revolution is going to be a very slow one; it won't be a significant factor in this century. Other revolutions will overtake it... The idea of designer babies . . . is just the reprogramming of the information processes in biology. But it's still biology, with all its profound limitations (KURZWEIL, 2005, p. 225-26).

Moreover, most of the emphasis on evolution by these writers relates to the mismatch between the ancestral environment and present-day needs. One is readily reminded of a very conspicuous mismatch, sugar dependence. Once useful under the harsh conditions of hunter-gatherer ways of life, today sugar only leads to weight problems, diabetes, and so on. Transhumanists stress that "in many ways we are stuck with the psychology and drives of our hunter-gatherer ancestors" (SAVULESCU; SANDBERG, 2012, p. 28). As a corollary, present ways of giving birth may be the best we could get in the past but, in modern conditions of living, this does not work 
anymore, and enhancement should happen here also. Even the drive for procreation may be scaled down.

Still another example is love. The evolutionary origins of love contribute to its own enhancement. From this perspective, "Underlying human love [there] is a set of basic brain systems for lust, romantic attraction and attachment that have evolved among mammals" (SAVULESCU; SANDBERG, 2008, p. 35). But evolution also harms love in our current context since it "can interfere with marital bliss in three main ways: through conferring different goals on men and women, through evolving relationship structures that promote inclusive fitness rather than happiness, and by way of a mismatch between current possibilities (e.g., lifespan) and evolved adaptations" (Ibid., p. 32-33).

There is little mention of the relationship between mothers, allomothers, and infants as a major source of love coming from our evolutionary past, or the abnegation of most of these actors to allow for the well-being of children.

\section{Problems with transhumanists' views on human birth}

Elsewhere, we briefly outlined issues like the ones above, around seven key themes related to transhumanism (CRUZ, 2013). Now we will summarize some of them to show in another fashion how transhumanism relates to evolution and human birth.

Mismatched ancestral environment-contemporary world. As we have seen, when confronting biological evolution transhumanists usually adopt two strategies. First, they suggest that evolution is a piece of "bad engineering," and that we, with a better knowledge of the processes of natural selection, may improve on nature's work. Second, they acknowledge that perhaps our biological makeup was optimal in an ancestral environment, but that many traits are now detrimental to our modern way of life. Both strategies may be found wanting. The first strategy captures only part of what evolution is all about, downplaying trade-offs that improved well-being in ancestral conditions. For humans, these trade-offs led to the creation of a strong cultural community, mainly centered on cooperative breeding. The second strategy 
minimizes the effect of ancestral environments on making humans very resilient, with the capability of adapting, through a suitable coevolution, to novel environments. Instead of trying to deal with the "mismatch" solely by freeing us from biological constraints, it might be better to adjust modern ways of life in accordance with lessons drawn from studies of human evolution (see BERGSMA, 2000, p. 403;414).

Mothers, babies, and birth canals. Transhumanists' negative views of human evolution carry little regard for reproduction as a major component in it-they may see little use for it in the future. But it may well be that the well-being of present and future humans, as well as what we value, are strongly connected to these processes, driven as they are by hormones and the mammalian brain. As we have seen with Trevathan and Narvaez, some current trends in birthing and childrearing, too reliant on medical intervention and regarding well-winnowed behaviors enabled by past gene-culture coevolution as outdated, have partially backlashed. However, these behaviors still are, and will be, essential for informing what creative humans are all about. There are many ways to obtain self-accomplishment other than parenthood, but it can be argued that having children and caring for them is, and it will be, the most common and democratic way of improving humanity.

Moreover, a balance of pleasure and pain is crucial for our well-being. Some transhumanists acknowledge this, but they are suspicious of present means to accomplish well-being. After all, they argue that natural selection is not about happiness, but fitness for reproduction (EARP; SANDBERG; SAVULESCU, 2012, p. 569). Yet, the same processes yield as trade-offs the means to achieve happiness, and parenthood has been a major source of happiness. Enhancement of love faces similar dilemmas. Love will always involve dramatic and unpredictable choices, as it can be seen in Hrdy's description of the modern world's expectations of motherhood: “Evolutionists like Trivers and Bowlby appeared to impose on women painful choices no man needs ever make: her aspirations versus her infant's well-being. Vocation or reproduction" (HRDY, 2000, p. 490). All the vicissitude and abnegation around having a baby and rearing her, which has been constant throughout our evolution up to now, is largely absent in transhumanist discourse. As we can draw from what has been argued above, all the happiness we can get from parenthood comes amid pain 
and suffering, even when many instances of the latter can be removed by technological means.

Babies, a problem or an opportunity? Despite claims to the contrary, the ideal picture ("what we value") in transhumanism is of a generic, genderless human or an empowered male (see the reference to the marathon runner in the beginning), so women's experiences and specific emotions are seldom considered. However, these experiences indicate that the suffering brought by birth pangs, though viewed as senseless by hedonistic and utilitarian considerations, may also bring about what is distinctive and sublime in the human species: the possibility of love. As Orli Dahan says:

However, what is interesting in relation to the intense pain of natural birth is that, although women have consistently rated it as an extreme pain, the experience is not necessarily negative. . . . It was found that labor pain is paradoxical and, thus, difficult to explain" (DAHAN, 2021, p. 4).

In sum, designer babies may require sophisticated technology and close medical observation, but this goes against contemporary trends of parents wishing to have their offspring in a more natural way. As Trevathan puts it, when criticizing the sophisticated technology around childbirth: "a crying baby . . . is no longer merely a being to be loved, but a problem to be solved"' (2010, p. 154).

In sum, we are still connected with our biological past, particularly in the case of begetting new generations, because the history of human evolution is so tightly related to child rearing. The difficulties associated with childbirth, extensive care with communal support, face-to-face interaction, storytelling, and rites of passage seem to be related to adaptation, and so they are deeply ingrained in our brains. Technological intervention should not uproot the drive for natality as a source of novelty in the human timeline, having such strong ties to our evolutionary past. As Larry Temkin puts it: "I think if the cost of immortality would be a world without infants and children, without regeneration and rejuvenation, it wouldn't be worth it" (TEMKIN, 2011, p. 365). There is no need to aim at immortality. Any enhancement and or transformation set only by a world of adults may lead to an anti-human world. To convey his ideas on the rights of lords over servants, Thomas Hobbes wrote long ago a thought experiment that illustrates the point: "Let us return again to the state of nature, and consider men as if but even now sprung out of the earth, and suddainly 
(like Mushromes) come to full maturity without all kind of engagement to each other." (HOBBES, 1983[1651], p. 117; see also SCHÜES, 2017, p. 103). Post-humans, in the same manner as robots, are thought of as adults from inception.

\section{Transhumanism, embodiment and human nature}

Now a final word about human nature in transhumanism. A few commentators have indicated that both bioconservatives and transhumanists share a common view of human nature. Tamar Sharon, for example, argues at length that these apparently "clashing accounts of human nature are not as antithetical as they may seem, however. Essentially, [...], they are both grounded in the humanist narrative of the human as an autonomous, unique and fixed entity" (SHARON, 2014, p. 3 passim). The problem for both parties is the body, not reason.

Sharing something in common with Sharon, philosopher Michael Hauskeller argues that there are in transhumanist thought two contrasting views of human nature. The first "one understands nature as that which confines us, setting limits to what we can do and be (... in form of our own bodies...), while the other understands nature as that which allows and indeed urges us to overcome all limits and boundaries" (HAUSKELLER, 2013, p. 64). In the same manner, he argues, these two natures work against each other, the "bad" one due to constraints and the good one due to its supposedly liberating character. The whole transhumanist project, still according to Hauskeller, assumes that "The true human is still to be created. And it is to be created by us" (Ibid.), as progress-oriented beings. To achieve god-like creativity, we must "fulfill our destiny and become truly human, we need to aspire to the highest. Potentially, we are all gods, and because we are and to the extent that we are, we ought to be gods" (Ibid., p. 66). In order to arrive at this goal, the confinements of our current nature (suffering, disease, death, so typical of our historicity) must be overcome. The biological body, in sum, is a hindrance to this project.

True, some transhumanists such as Nick Bostrom do have room for embodiment in their proposals for the future, but Bostrom himself says that "A first 
priority is to abandon the unquestioning assumption that human nature and the human condition will remain fundamentally unchanged throughout the current century" (BOSTROM, 2006, p. 48). What is this nature and condition constituted of? As he says about our basic biological capacities, which have remained more or less constant throughout history: "We still eat, sleep, defecate, fornicate, see, hear, feel, think and age in pretty much the same ways as the contemporaries of Sophocles did. But we may now be approaching a time when this will no longer be so" (Ibid., p. 40). In other words, these very ungodly things such as to defecate and to fornicate (as well as giving birth) are apparently bound to disappear.

Fornication may still be around, but with clean bodies that have no otherness, no babies, no challenge to our wishes: "Sexbots will electrocute our flesh with climaxes twice as gigantic because they'll be more desirable, patient, eager, and altruistic than their meat-bag competition" (PELLISSIER, 2009; emphasis author's). At any rate, sex will not be related to procreation anymore-it will be something more akin to a sophisticated masturbation. More recently, Robert Manzocco spoke about the "Flesh of the Future" (or absence thereof). Again, sex is uncoupled from reproduction (MANZOCCO, 2019, p. 183), leading to a postgender society where embodiment is strictly under our control (Ibid., p. 241; see also PEED, 2016, p. 506). The final destination is a real "telepathic civilization" (Ibid., p. 179), where flesh can be eventually dispensed with: "We have eliminated the heart, lungs, red and white blood cells, platelets, pancreas, thyroid and all of the organs that produce hormones, kidneys, bladder, liver, the lower part of the esophagus, stomach and intestines" (Ibid., p. 184). The remainder will follow suit.

It is true that these are exaggerated claims, but it is a likely scenario for proposals of enhancement. Nevertheless, these claims still have a basis on an interpretation of human nature: the pursuit of happiness, the towering place attributed to reason, the disregard for the biological, the lack of concern for births, at least when accompanied by sweat, blood, sticky vernix and tears. Everything that the biological has of good in other contexts is transcended in the post-biological. Human nature stays out of the boundaries of the past and the given, and it is projected into some ideal that resembles Christian Eschatology, as so many have pointed out (see, e.g., TIROSH-SAMUELSON, 2012, p. 716). 


\section{Conclusion}

Fiona Woollard's unpretentious piece on birth, which highlights GERA (gendered embodied reproductive achievements), gave us the opportunity to link birth and human nature, however the latter is defined. Yet, any definition should be gendered, as indicated by Woolard herself, and scholars of the evolution of birth such as Dahan, Trevathan and Narvaez. All of them speak of trade-offs in evolution, where processes which causes us suffering are counterbalanced by positive, very human experiences.

Next, we presented opinions of some philosophers of birth (who give prominence to the concept of natality), which are congruent with those indicated in the preceding paragraph. Although these opinions are contrary to any fixed, maleoriented human nature, they still suggest that behaviors around births are irreplaceable relations, although contingent.

Turning then to transhumanism, we had the opportunity to see the overall disregard for the outcome of human evolution: "human nature" should be "corrected and overcome." Suspicion is greater when it comes to reproduction and giving birth. For transhumanism, "human nature" is something of the future, transcending the ambiguous body, subject as it is to suffer and death. It is a philosophy of an adult world, regarding birth and childhood as accessory to the pursuit of excellence that the movement is seeking. However, minimizing birth because of its downside ignores trade-offs in evolution which have already enhanced love, care and cooperationhumans are as they are precisely because of this continuous tension among ambiguous trade-offs. The body and the embodied emotions and mind, hallmarks of past evolution, are therefore devaluated, as if they were not necessary for our identity. But birth is not a problem to be solved, so natality here stands for new opportunities and configurations of the human. 
BERGSMA, A. Transhumanism and the Wisdom of Old Genes: Is Neurotechnology a Source of Future Happiness? Journal of Happiness Studies, v. 1, p. 401-17, 2000.

BOSTROM, N. Welcome to a world of exponential change. In: MILLER, P.; WILDSON, J. (Eds.). Better Humans? The politics of human enhancement and life extension. London: Demos, 2006. p. 40-50.

BOSTROM, N.; SANDBERG, A. The Wisdom of Nature: An Evolutionary Heuristic for Human Enhancement. In: SAVULESCU, J.; Nick BOSTROM, N. Human Enhancement. Oxford: Oxford University Press, 2008. p. 374-416.

BUCKLEY, S. J. Undisturbed Birth: Nature's Blueprint for Ease and Ecstasy. Journal of Prenatal and Perinatal Psychology and Health, v. 17, n. 4, p. 262-288, 2003.

CARTWRIGHT, J. Evolution and Human Behaviour. Darwinian perspectives on the human condition. 3. ed. London: Palgrave / Macmillan, 2016.

CRUZ, Eduardo R. Transhumanism and the fate of natality: an introduction. Zygon, vol. 48, no. 4 (December), p. 916-935, 2013.

DAHAN, O. Birthing consciousness: A lacuna in evolutionary psychological science. New Ideas in Psychology, v. 60, 2021. DOI https://doi.org/10.1016/j.newideapsych.2020.100822.

DOWNES, S. M. Evolutionary Psychology. Stanford Encyclopedia of Philosophy, Fall Edition, 2018. Available at https://plato.stanford.edu/entries/evolutionary-psychology/. Accessed in: 20 dec. 20, 2018.

DOWNES, S. M.; MACHERY, E. (eds.). Arguing About Human Nature: Contemporary Debates. New York: Routledge, 2013.

EARP, B. D.; SANDBERG, A.; SAVULESCU, J. "Natural Selection, Childrearing, and the Ethics of Marriage (and Divorce): Building a Case for the Neuroenhancement of Human Relationships.” Journal of Philosophy and Technology, v. 25, p. 561-87, 2012.

GUENTHER, Lisa. The gift of the other: Levinas and the politics of reproduction. Albany, NY: State University of New York Press, 2006.

HAUSKELLER, M. Human Nature from a Transhumanist Perspective. Existenz, v. 8, n. 2, p. 64-69, 2013.

HOBBES, T. Philosophicall Rudiments Concerning Government and Society. De Cive: the English version entitled in the first edition (The Clarendon edition of the philosophical works of Thomas Hobbes; v. 3) Oxford: Oxford University Press at The Clarendon Press, 1983 [1651].

HRDY, S. B. Mother Nature: A History of Mothers, Infants, and Natural Selection. New York: Random House, 2000.

KATZ, B. F. Neuroengineering the Future: Virtual Minds and the Creation of Immortality. Hingham, MA: Infinity Science Press, 2008. 
KEELING, D. M. History of (Future) Progress: Hyper-Masculine Transhumanist Virtuality. Critical Studies in Media Communication, v. 29, n. 2, p. 132-148, 2012. DOI: 10.1080/15295036.2012.666803.

KRONFELDNER, M.; Neil ROUGHLEY, N.; TOEPFER, G. Recent Work on Human Nature: Beyond Traditional Essences. Philosophy Compass, v. 9, n. 9, p. 642-652, 2014. DOI 10.1111/phc3.12159.

KURZWEIL, R. The Singularity Is Near. When Humans Transcend Biology. New York: Viking Press, 2005.

LOPES, W. E. S. O transhumanismo e a questão antropológica. Revista de Filosofia Aurora, Curitiba, v. 32, n. 55, p. 36-61, jan./abr. 2020.

MANZOCCO, R. Transhumanism - Engineering the Human Condition. History, Philosophy and Current Status. Cham, CH - Chichester: Springer-Praxis, 2019.

MCNAMEE, M. J. Transhuman Athletes and Pathological Perfectionism: Recognising Limits in Sports and Human Nature. In: TOLLENEER, J.; STERCKX, S.; BONTE, P. (eds) Athletic Enhancement, Human Nature and Ethics. Dordrecht: Springer, 2013. DOI https://doi.org/10.1007/978-94-007-5101-9_10.

MIAH, A. Towards the transhuman athlete: therapy, non-therapy and enhancement. Sport in Society: Cultures, Commerce, Media, Politics, v. 13, n. 2, p. 221-233, 2010. DOI: 10.1080/17430430903522947.

MORE M. "Letter to Mother Nature." In: MORE, M.; VITA-MORE, N. (ed.). The Transhumanist Reader: Classical and Contemporary Essays on the Science, Technology, and Philosophy of the Human Future, Oxford: Wiley Blackwell, 2013[1999]. p. 449-50.

NARVAEZ D.; et al. The Value of Using an Evolutionary Framework for Gauging Children's Well-Being. In: NARVAEZ, D., et al. (Eds.). Evolution, Early Experience and Human Development: From Research to Practice and Policy. New York: Oxford University Press, 2013. p. 03-30.

PEED, E. The Splintering and Controversy of Transhumanism. In: LEE, N. (ed.). Google It. Total Information Awareness. New York: Springer, 2016. p. 499-510.

PELLISSIER, H. Sexbots Will Give Us Longevity Orgasm. December 11, 2009. Available at https://hplusmagazine.com/2009/12/11/sexbots-will-give-us-longevity-orgasm/. Access in: 01 nov. 2019.

POWELL, R.; BUCHANAN, A. Breaking Evolution's Chains: The Prospect of Deliberate Genetic Modification in Humans. Journal of Medicine and Philosophy, v. 36, n. 6-27, 2011.

SAvUlESCU, J.; KAHANE, G. The Moral Obligation to Create Children with the Best Chance of the Best Life. Bioethics, v. 23, p. 274-90, 2009.

SAVULESCU, J.; SANDBERG, A. Neuroenhancement of Love and Marriage: The Chemicals between Us. Neuroethics, v. 1, p. 31-44, 2008.

SAVULESCU, J.; SANDBERG, A. Engineering Love. New Scientist, v. 214, p. 28-29, 2012. 
SCHÜES, C. Birth. In: SOLOMON, M.; SIMON, J. R.; KINCAID, H. The Routledge companion to philosophy of medicine. New York: Routledge/Taylor \& Francis, 2017.

SHARON, T. Human Nature in an Age of Biotechnology: The Case for Mediated Post humanism. Dordrecht: Springer, 2014.

SÖDERBÄCK, F. Birth. In: GOODMAN, R. T. The Bloomsbury Handbook of 21st-Century Feminist Theory. London: Bloomsbury Academic, 2019. p. 59-79.

STONE, A. Being Born. Birth and Philosophy. Oxford: Oxford University Press, 2019.

TEMKIN, L. Is Living Longer Living Better? In: SAVULESCU, S.; MEULEN, R.; KAHANE, G. Enhancing Human Capacities. Oxford: Wiley Blackwell, 2011. p. 350-367.

TIROSH-SAMUELSON, H. Transhumanism as A Secularist Faith. Zygon: Journal of Religion and Science, v. 47, n. 4, p. 710-734, 2012. DOI https://doi.org/10.1111/j.14679744.2012.01288.x.

TREVATHAN, W. R. Ancient Bodies, Modern Lives: How Evolution Has Shaped Women's Health. Oxford: Oxford University Press, 2010.

TREVATHAN, W.; ROSENBERG, K. Human Evolution and the Helpless Infant. In: TREVATHAN, W.; ROSENBERG, K. Costly and Cute: Helpless Infants and Human Evolution. Santa Fe: School for Advanced Research Press, 2016. p. 1-28.

TYLER, I. Introduction: Birth. Feminist Review, v. 93, n. 1, p. 1-7, 2009.

WOLBRING, G. What next for the human species? Human performance enhancement, ableism and pluralism. Development Dialogue, n. 52, p. 141-163, 2009.

WOLBRING, G. Obsolescence and body technologies. Dilemata, v. 2, n. 4, p. 67-83, 2010.

WOOLLARD, F. Philosophy can explain what kind of achievement it is to give birth. Aeon/Psyche, 2020. Available at: https://psyche.co/ideas/philosophy-can-explain-whatkind-of-achievement-it-is-to-give-birth?utm. Access in: August 20, 2020.

YOUNG, S. Designer Evolution: A Transhumanist Manifesto. Amherst, NY: Prometheus Books, 2006.

ZANER, R. M. Visions and Re-visions: Life and the Accident of Birth. In: Harold, W. B.; TIMOTHY K. C. Is Human Nature Obsolete? Genetics, Bioengineering, and the Future of the Human Condition, ed. Cambridge, MA: MIT Press, 2005. p. 177-208.

RECEBIDO: 07/05/2021

RECEIVED: 05/07/2021

APROVADO: 09/07/2021

APPROVED: 07/09/2021 